AKRUAL 2 (1) (2010): 43-54 $e$-ISSN: 2502-6380

AKRUAL

Jurnal Akuntansi

http://fe.unesa.ac.id/ojs/index.php/akrl

\title{
COST-VOLUME-PROFIT ANALYSIS UNTUK KONDISI UNCERTAINTY
}

\author{
Wiwiek Dianawati \\ Fakultas Ekonomi dan Bisnis Universitas Airlangga \\ Email: wiwiek.dianawati@yahoo.com
}

Artikel diterima: 15 Januari 2010

Revisi terakhir: 17 Maret 2010

\begin{abstract}
Hotels tend to have a high level of fixed cost owing to the levels of investment required. This should result in above normal profits in good times, as variable costs remaining will form a smaller proportion of additional revenue. However, while high profits can be achieved above the break-even point, high losses will result if revenue is significantly reduced. Thus much attention is given to the traditional CVP model (which ignores uncertainty), as failure to cover fixed costs in the long term can result bankruptcy for organization. This article examines the basic CVP model and describes how to include uncertainty during the decision making process.
\end{abstract}

Key words: CVP model, Break-Even Point, uncertainty.

\begin{abstract}
Abstraksi
Perusahaan jasa seperti Hotel cenderung memiliki investasi yang besar pada fixed cost. Sehingga profit diatas normal akan dicapai bila variabel cost memiliki proporsi yang lebih kecil daripada tambahan revenue. Profit tinggi akan dicapai bila revenue jauh diatas break-even point dan kerugian akan diperoleh jika ada penurunan revenue yang signifikan. Untuk itu perlu memberi perhatian pada model CPV tradisional (yang mengabaikan uncertainty), karena kegagalan menutup fixed cost untuk jangka panjang akan menyebabkan perusahaan mengalami kebangkrutan. Artikel ini mencoba mengulas model CVP, dengan memasukkan uncertainty dalam proses pengambilan keputusan.
\end{abstract}

Kata kunci: Model CVP, BEP, ketidakpastian.

\section{PENDAHULUAN}

Pemahaman atas perilaku biaya menjadi hal yang krusial, karena akuntan manajemen harus menentukan mana biaya yang tetap dan mana yang variabel khususnya pada saat prediksi biaya didasarkan pada berbagai level produksi. CVP (Cost, Volume, Profit) analysis memerlukan informasi perihal biaya tetap, biaya variabel serta informasi mengenai revenue guna kepentingan memprediksi profit 
dalam berbagai tingkat volume produksi. Penelitian ini diharapkan bisa mengetahui tingkat BEP baik dalam unit maupun dalam moneter; berapa unit yang diproduksi pada target profit yang diinginkan; berapa penjualan dalam moneter yang harus dilakukan pada target profit yang diharapkan, dsb. CVP chart yang dibuat akan mampu untuk melihat hubungan antara volume produksi dengan revenue, cost dan profit dan mampu menunjukkan efek dari perubahan volume barang yang di produksi dengan profit yang dicapai.

Beberapa model memiliki beberapa kekurangan karena asumsi yang terkandung di dalamnya yaitu semua biaya variabel dan biaya tetap diketahui dengan pasti (Phillips, 1994). Asumsi terakhir ini tampaknya aneh sebagai manajer untuk membuat keputusan dalam lingkungan turbulensi. Dengan demikian manfaat keseluruhan model harus dipertanyakan.

Dimasukkannya ketidakpastian dalam model CVP bukan ide yang baru, seperti beberapa penulis telah menulis tentang topik ini. Paper dari Jaedicke dan Robichek's menulis mengenai bagaimana probabilitas distribusi normal dapat digunakan untuk menunjukkan bagaimana satu variabel (harga) mempengaruhi variabel lain (biaya variabel), dalam sebuah ketidakpastian yang diketahui terlebih dahulu. Tulisan ini bertujuan untuk mengetahui hubungan antara biaya, volume, penjualan, dan laba dalam kondisi ketidak pastian.

\section{KAJIAN PUSTAKA}

\section{Analisis Cost-Volume-Profit}

Analisis CVP merupakan alat analisis bagi manajemen tentang hubungan antara biaya, volume penjualan, dan laba. Dengan melakukan analisis CVP dapat diketahui hubungan antara perubahan volume penjualan dan perubahan terhadap harga jual dan jumlah biaya (biaya tetap dan variabel). Jadi, manajemen dapat menentukan volume penjualan dan bauran produk yang dibutuhkan untuk mencapai tingkat laba yang diharapkan dengan sumber daya yang dimiliki.

Analisis CVP tidak hanya bermanfaat untuk organisasi yang berorientasi pada laba, tetapi juga dapat digunakan untuk organisasi yang tidak berorientasi pada laba. Organisasi tersebut perlu memahami bagaimana biaya dapat dipengaruhi oleh perubahan volume kegiatan untuk membantu organisasi dalam mengendalikan biaya. Dalam melakukan analsis CVP didasarkan pada suatu asumsi bahwa:

1. Semua biaya dapat dipisahkan menjadi biaya tetap dan biaya variabel.

2. Jumlah biaya tetap tidak berubah dalam kisaran tertentu dari data yang dianalisis.

3. Biaya variabel berubah seiring dengan perubahan dalam volume produk atau kegiatan dalam kisaran tertentu dari volume yang dianalisis. 
Dalam upaya memisahkan antara biaya tetap dan biaya variabel untuk biaya yang sifatnya semi variabel, bisa dilakukan dengan melakukan analisis perilaku biaya dengan menggunakan salah satu dari beberapa metode pemisahan. Metode yang bisa digunakan adalah sebagai berikut: (Carter-Usry,2002,3/6-15)

1. High and Low points Method

2. Statistical Scattergraph Method

3. Method of Least Squares

\section{The High and Low Method}

Dalam metode ini unsur beban semi variabel yang bersifat tetap dan variabel dihitung dari dua titik data. Titik data yang dipilih adalah data historis yang sedang dianalisis. Apabila periode yang mempunyai tingkat kegiatan tertinggi dan terendah tidak sama dengan periode yang mempunyai biaya tertinggi dan terendah yang sedang dianalisis maka tingkat kegiatan-lah yang harus digunakan untuk menentukan seleksi. Asumsi nya bahwa perbedaan biaya pada kedua tingkat kegiatan diakibatkan oleh kegiatan yang terukur dan karena itu merupakan biaya variabel murni. Tarif variabel ditentukan dengan membagi selisih beban/biaya dengan selisih kegiatan. Perbedaan antara beban total dengan beban variabel adalah beban tetap.

\section{The Statistical Scattergraph Method}

Dalam metode ini berbagai biaya dimasukkan digambarkan pada garis vertikal dan kegiatan terkait digambarkan sepanjang garis horisontal. Kemudian ditarik garis yang ada diantara titik tersebut. Pada umumnya jumlah titik data diatas garis harus sebanyak titik data dibawah garis. Kelemahan metode ini adalah garis yang digambarkan melalui plot data hanya didasarkan pada interpretasi visual. Metode ini lebih baik daripada metode pertama karena sudah mempertimbangkan tidak hanya dua titik tetapi banyak titik.

\section{The Method of Least Square}

Metode ini secara matematis menghasilkan garis regresi linear yang melalui serangkaian titik, sehingga jumlah pengkuadratan deviasi (selisih) vertikal antara titik titik dengan garis akan minimum. Metode ini lebih akurat daripada metode scattergraph karena observasi visual tidaklah secermat observasi matematis. Terlebih dahulu lakukan uji normalitas data, jika ada data yang tidak normal keluarkan dulu dari sampel data. Analisis korelasi diperlukan untuk melihat kekuatan hubungan antara dua variabel yang dipakai yaitu variabel dependen dan independen, Bila semua titik yang digambarkan terletak pada garis regresi maka ada korelasi yang sempurna antara variabel yang dipakai. Juga bisa menggunakan teori statistik untuk menghitung korelasi, dengan hasil $r$ antara 0 hingga 1 . Semakin besar $r$ semakin kuat hubungan. Bila hasilnya kuat, maka variabel yang independen harus diganti karena tidak memiliki hubungan yang kuat dengan variabel dependennya, meskipun penggunaan metode perhitungan ini biasanya menghasilkan perilaku biaya yang dapat 
diandalkan dibandingkan penggunaan penilaian manajerial yang sederhana, namun manajemen haruslah menyadari bahwa hasil yang diperoleh tergantung pada historis.

Jika keadaan abnormal atau tidak biasa yang terjadi dalam satu periode atau lebih dimasukkan ke dalam data base, observasi yang mencerminkan ketidaknormalan itu harus di kesampingkan dari model. Dalam hal ini, penilaian manajerial memainkan peranan penting dalam analisis perilaku biaya.

\section{Break Even Point-BEP}

Titik impas (break event point-BEP) adalah suatu titik dimana jumlah pendapatan sama dengan jumlah biaya, dengan kata lain laba sama dengan nol.

Dengan adanya analisis titik impas (BEP-analysis), perusahaan dapat merencanakan tingkat volume produksi dan atau penjualan yang akan menghasilkan laba yang diharapkan. Titik impas dapat dihitung dalam volume penjualan (unit) atau dalam nilai moneter (rupiah). Untuk menghitung titik impas dalam unit dapat menggunakan rumus dibawah ini.

$$
\mathrm{BEP}(\mathrm{Unit})=\mathrm{FC} /(\mathrm{P}-\mathrm{VC})
$$

\section{Keterangan:}

$\mathrm{BEP}($ unit $)=$ titik impas dalam unit.

$\mathrm{FC}=$ jumlah biaya tetap (fixed cost).

$\mathrm{P}=$ harga jual per unit (price)

$\mathrm{VC}=$ biaya variabel per unit (variable cost)

Sementara untuk menghitung titik impas dalam nilai moneter dapat menggunakan persamaan berikut:

$$
\mathrm{BEP}(\mathrm{Rupiah})=\mathrm{FC} /(1-(\mathrm{VC} / \mathrm{p}))
$$

Analisis CVP dapat digunakan untuk menentukan volume penjualan yang diperlukan untuk menentukan target profit yang diharapkan. Target laba yang diharapkan dimasukkan dalam persamaan dasarnya sehingga tingkat penjualan yang diharapkan untuk menutup biaya dan target profit yang diharapkan bisa dihitung:

Target Profit dan Fixed

$$
\text { Cost }
$$

Unit yang dikehendaki untuk mencapai target profit $=$

Contribution margin

per unit

Contribution margin perunit $=\mathrm{P}-\mathrm{VC}$

$\mathrm{P}=$ harga jual per unit (price)

$\mathrm{VC}=$ biaya variabel per unit (variable cost) 
Asumsi CVP analysis adalah:

1. Biaya semi variabel dapat dipisahkan menjadi tetap dan variabel.

2. Biaya tetap tidak akan berubah (konstan), dan biaya variabel akan bervariasi secara proporsional dengan volume penjualan

3. Produk/jasa tunggal, atau jika multiproduk maka komposisi penjualannya konstan

4. Volume penjualan merupakan satu-satunya faktor yang mempengaruhi biaya dan pendapatan dalam rentang yang relevan.

5. Variasi pendapatan berubah secara proporsional dengan volume

6. Tidak ada perubahan dalam tingkat persediaan atau keuntungan ditentukan berdasarkan margin.

7. Tingkat efisiensi tetap tidak berubah

Dengan melihat asumsi yang melekat pada CVP analysis diatas, berarti untuk kondisi yang turbulensi dimana unsur ketidakpastiannya tinggi, CPV analysis diatas tidak bisa digunakan. Tetapi dengan bantuan statistik, dengan asumsi distribusi normal, kondisi ketidakpastian dimasa mendatang bisa tetap dihitung atau diprediksi dengan menggunakan CPV analysis modifikasi.

\section{Distribusi normal}

Distribusi normal adalah berbentuk lonceng dan simetris pada mean dan median. Untuk memastikan sebuah distribusi normal biasanya perlu untuk menentukan mean $(\mu)$ dan standar deviasi $(\sigma)$. Rumus yang digunakan:

$$
Z=\frac{X-\mu}{\sigma}
$$

$$
\begin{aligned}
\text { dimana } X & =\text { Nilai variabel } \\
\mu & =\text { Rata-rata nilai } \\
\sigma & =\text { standar deviasi }
\end{aligned}
$$

contoh, jika suatu variabel, $X$, yang memiliki distribusi normal dengan $\mu$ sebesar 200, dan $\sigma$ sebesar 20, dan pengamatan aktual 230, Z-nilai digunakan untuk menentukan probabilitas dari kejadian ini.

Dengan menggunakan persamaan di atas, $Z$ dapat dihitung sebagai berikut:

$$
Z=\frac{230-200}{20}=1,5
$$


Nilai Z 1,5 ditunjukkan diagram pada Gambar 1, dan karena luas total di bawah kurva distribusi normal adalah sama dengan satu, bagian diarsir adalah sama dengan probabilitas mendapatkan nilai sebesar 1,5 $\sigma$. Untuk mengkonversi nilai- $Z$ dari 1,5 ke perkiraan probabilitas yang sebenarnya, perlu untuk menggunakan tabel distribusi normal yaitu melihat nilai $\mathrm{Z}$ dikolom $\mathrm{Z}$ yang ditarik ke kanan untuk melihat probabilitasnya. Probabilitas lebih dari 1,5 $\sigma$ adalah sebesar 0,9332 dan probabilitas kurang 1,5 $\sigma$ sebesar 0,0668. Sedangkan gambar 2 menggambarkan bahwa sekitar, $99,7 \%$ terletak pada $1 \sigma, 95,4 \%$ terletak pada $2 \sigma$ dan $68,3 \%$ terletak pada $3 \sigma$.

\section{Analisis CPV Ketidakpastian}

Berikut ini adalah contoh penggunaan analisis CVP dengan ketidakpastian pada industri jasa, yaitu industri jasa perhotelan yaitu Hotel 'Welsh'. Industri perhotelan menggunakan analisis $C V P$ dalam pengambilan keputusan terhadap berbagai alternatif tindakan, baik dalam merealisasikan anggaran maupun dalam merencanakan laba. Industri perhotelan memiliki karakteristik yang berbeda dengan industri lainnya. Dalam industri perhotelan, perusahaan dituntut bagaimana menghasilkan dan memasarkan jasa perhotelan bagi konsumen yang membutuhkan jasa tersebut.

Pendapatan industri perhotelan dipengaruhi oleh tingkat kepadatan/hunian. Oleh karena itu, dalam menyusun perencanaan laba, manajemen harus mempertimbangkan tingkat kepadatan yang diprediksikan akan terjadi. Manajemen hotel dalam merencanakan labanya perlu melihat realisasi tahun-tahun sebelumnya dan dibandingkan dengan para kompetitor, yang kemudian dibuat anggaran. Anggaran tersebut berisikan taksiran pendapatan, biaya serta laba yang ingin dicapai. Perkiraan pendapatan kamar dihitung dari occupied room (jumlah kamar yang tersedia $\mathrm{x}$ jumlah hari dalam setahun $\mathrm{x}$ perkiraan persen tingkat hunian) dikalikan dengan tarip kamar rata-rata. Setelah dikurangi dengan biaya-biaya maka diketahui laba departemen. Pada usaha perhotelan ini, tidak ada pengklasifikasian biaya-biaya yang terjadi berdasarkan volume kegiatan misalnya biaya tetap, biaya variabel, dan biaya semivariabel, sehingga menyulitkan manajemen dalam perencanaan laba. Selain itu perusahaan belum menggunakan metode yang memadai untuk mengetahui berapa besarnya volume penjualan yang harus dicapai untuk dapat menutupi seluruh biaya yang digunakan dan untuk memperoleh laba yang direncanakan.

Berdasar pengalaman tahun-tahun lalu, tingkat hunian adalah 57 persen yang setara dengan 26.006 kamar akan yang dijual periode yang akan datang. Untuk melakukan analisis CVP perlu untuk menyiapkan laporan laba rugi kontribusi yang bisa dilihat pada tabel 1 . 
Tabel 1. Laporan Laba/Rugi Hotel'Welsh'

Tahun 20X0

\begin{tabular}{|c|c|c|c|c|c|}
\hline Departemen & $\begin{array}{c}\text { Penjualan } \\
(\mathfrak{f})\end{array}$ & $\begin{array}{r}\text { HPP } \\
(\mathfrak{f})\end{array}$ & $\begin{array}{c}\text { Beban Gaji } \\
\text { Beban Lain } \\
\text { (f) }\end{array}$ & $\begin{array}{c}\text { Total } \\
\text { Beban } \\
(\mathfrak{( f )}\end{array}$ & $\begin{array}{c}\text { Keuntungan } \\
\text { Departemen } \\
(\mathfrak{f})\end{array}$ \\
\hline Kamar & 881,500 & & 282,125 & 282,125 & 599,375 \\
\hline Makanan dan minuman & $1,025,375$ & 345,375 & 351,125 & 696,500 & 328,875 \\
\hline \multirow{2}{*}{ Minor operasi Tata Usaha } & 95,584 & 24,827 & 11,507 & 36,334 & 59,250 \\
\hline & $2,002,459$ & 370,202 & 644,757 & $1,014,959$ & 987,500 \\
\hline \multicolumn{6}{|c|}{$\begin{array}{l}\text { Dikurangi: Biaya operasi yang } \\
\text { belum dibagi }\end{array}$} \\
\hline Admin umum. Dan & & & 109,285 & & \\
\hline Pemasaran & & & 55,159 & & \\
\hline Energi & & & 77,325 & & \\
\hline Properti operasi & & & 57,736 & & 515,500 \\
\hline Biaya Tetap & & & 215,995 & & \\
\hline Laba bersih sebelum pajak & & & & & 472,000 \\
\hline
\end{tabular}

Sumber: Phillips, Paul A.1994

Margin kontribusi sama dengan penjualan dikurangi biaya variabel.Untuk menentukan biaya variabel perlu memisahkan total biaya ke dalam komponen biaya tetap dan variabel (bisa digunakan satu dari 3 metode pemisahan yang ada).

Biaya penjualan, upah langsung, dan beban langsung sangat erat terkait dengan volume penjualan, dan diasumsikan merupakan biaya variabel. Sedang biaya seperti gaji manajerial dan biaya departemen (termasuk energi, pelatihan, telepon dan biaya pemasaran) tidak sepenuhnya tetap maupun variabel, dan dikenal sebagai biaya semi variabel.

Tabel 2 menunjukkan laporan laba/rugi kontribusi, yang untuk tujuan ilustrasi dibuat setelah memisahkan biaya semi variabel ke elemen tetap dan variabel dengan membagi mereka masing-masing 80/20. Tentu, hal ini tergantung kepada individu untuk memisahkannya dalam kegiatannya dengan memanfaatkan salah satu dari berbagai teknik untuk menentukan proporsi dan variabel dan biaya tetap.

Perlu dicatat bahwa hotel Welsh mempunyai biaya operasional tetap yang tinggi. Jika dibandingkan dengan volume penjualan, biaya variabel sebesar $24,9 \%$ dan biaya tetap 51,5\%. Dan jika dibandingkan dengan total biaya, biaya variabel mewakili 32,6 persen, dan biaya tetap 67,4 persen. Persentase biaya tetap yang tinggi mengakibatkan hotel Welsh mempunyai ketidakstabilan keuntungan yang tinggi. 


\section{Tabel 2. Hotel Welsh Laporan Laba Rugi Kontribusi Tahun 20X0}

\begin{tabular}{|c|c|c|c|c|c|c|}
\hline \multirow[b]{2}{*}{ Departemen } & \multicolumn{2}{|l|}{ njualan } & \multicolumn{2}{|l|}{ Biaya Var. } & \multicolumn{2}{|l|}{ Kontribusi } \\
\hline & $(£)$ & $(\%)$ & $(£)$ & $(\%)$ & $(£)$ & $(\%)$ \\
\hline Kamar & 881,500 & 100 & 56,425 & 6.4 & 825,075 & 93.6 \\
\hline Makanan dan minuman & $1,025,375$ & 100 & 415,600 & 40.5 & 609,775 & 59.5 \\
\hline \multirow[t]{2}{*}{ MOD } & 95,584 & 100 & 27,128 & 28.4 & 68,456 & 71.6 \\
\hline & $2,002,459$ & 100 & 499,153 & 24.9 & $1,503,306$ & 75.1 \\
\hline \multicolumn{7}{|l|}{ Dikurangi: } \\
\hline \multicolumn{3}{|c|}{ Biaya operasi yang belum dibagi } & 515,500 & & & \\
\hline \multicolumn{3}{|c|}{80 persen dari biaya departemen } & 515,806 & & $1,031,306$ & 51.5 \\
\hline \multicolumn{3}{|c|}{ Laba bersih sebelum pajak } & & & 472,000 & 23.6 \\
\hline
\end{tabular}

Setelah memisahkan biaya tetap dan biaya variabel, memungkinkan untuk menghitung kontribusi per kamar yang dijual:

Margin Kontribusi Perunit $=$ Kontribusi

Margin Kontribusi Per unit $=\frac{1.503 .306}{26,006}=£$------ 57,81.

Setelah itu menetapkan break even point dihitung:

$$
\text { BEP = - } \frac{£ 1.031 .306}{£ 57,81 .}
$$

Setelah sebelumnya menyatakan bahwa jumlah kamar yang dijual mengikuti distribusi normal, manajer umum (GM), bekerja sama dengan kepala departemen (Head Of Department) untuk divisi kamar harus menentukan angka untuk jumlah kamar yang terjual (mean), sehingga ada kemungkinan 50/50 kesempatan jumlah kamar yang sebenarnya dijual berada di atas atau di bawah mean. Misalkan, setelah penyusunan anggaran tahunan, 26.006 kamar dipilih sebagai mean. Dalam contoh ini, kebetulan jumlah kamar yang dijual tahun sama dengan rata-rata sebelumnya (lagi, terserah kepada pembaca untuk menentukan angka yang tepat). Ketika mean sudah ditetapkan maka deviasi standar dapat dipertimbangkan. 
Untuk menetapkan standar deviasi kamar dijual perlu untuk menerapkan teori probabilitas. Berdasarkan pengalaman masa lalu, GM dan HOD-nya memutuskan bahwa ada kemungkinan 50/50 bahwa jumlah kamar yang dijual akan berada sekitar 2.000 kedua sisi dari mean (lihat Gambar 3). Sejak sekitar 50 persen dari luas area di bawah kurva normal yang didistribusikan terletak di dalam $+/-0.67 \sigma$ dari mean (lihat Gambar 1), maka $1 \sigma$ adalah sebesar 3.000 kamar. Setelah memenuhi persyaratan untuk distribusi normal, maka bisa menetapkan probabilitas pada tingkat laba yang berbeda. Misalkan bahwa GM Welsh bekerjasama dengan asisten manajernya ingin menentukan pada keadaan break even, laba sebesar $£ 500,000, £ 600.000$, atau $£ 700,000$ pada tahun depan.

(1) probabilitas pada break event $=(17.840-26.006) / 3.000=-2,72$

Break even point berada $2.72 \sigma$ dari mean dalam distribusi standar normal. Sebagai distribusi simetris, daerah untuk nilai negatif dan positif adalah sama. Estimasi probabilitas dapat diperoleh dengan kolom kiri tabel distribusi normal pada 2,7, dan kemudian pindah ke kolom menuju 0,02. Diperoleh 0,00326 merupakan probabilitas tidak mencapai titik impas. Dengan kata lain, probabilitas sekurang-kurangnya pada break even point adalah sebesar (10,00326) $=0,997$, yaitu 99,7\%

(2) probabilitas sekurang-kurangnya laba $£ 500,000$

Jumlah kamar yang perlu dijual untuk mendapatkan kontribusi yang akan menghasilkan laba bersih sebesar $£ 500 \mathrm{~K}$ adalah:

$=($ Biaya tetap + Laba diinginkan $) /$ Kontribusi per kamar

$=(£ 1.031 .306+£ 500.000) / £ 57,81=26.489$

$Z$-value $=26.489-26.006=0.161 \sigma$, yang sama dengan probabilitas 0,4364 , yakni 43,6 persen.

(3) probabilitas sekurang-kurangnya laba $£ 600,000$

Jumlah kamar yang dijual:

$(£ 1.031 .306+£ 600,000) / £ 57,81=28.218$

Z-value $=(28.218-26.006) / 3000=0.737 \sigma$, yang merupakan probabilitas 0,2296 , yakni 23 persen.

(4) probabilitas sekurang-kurangnya laba £ 700,000

Jumlah kamar yang dijual:

$(£ 1.031 .306+£ 700,000) / £ 57,81=29.948$

$Z$-value $=29.948-26.006=1.314 \sigma$, yang sama dengan probabilitas 0,0951 , yaitu 9,51 persen.

Dari hasil perhitungan untuk Hotel Welsh, lebih bijaksana bagi GM untuk tidak berpikiran untuk menghasilkan laba $£ 600.000$ atau lebih karena sebelumnya tidak pernah tercapai dengan peluang kurang dari 30 persen.

Artikel ini telah menunjukkan cara untuk memasukkan ketidakpastian dalam model analisis CVP. Penulis berpendapat bahwa setiap GM menolak risiko, akan mendapat manfaat dari penggunaan teori probabilitas untuk pengambilan keputusan jangka 
pendek. Namun, pengguna tidak harus memperlakukan model ini sebagai obat mujarab karena tergantung pada data dan asumsi yang digunakan.

Oleh karena itu tampaknya perlu untuk menyebutkan beberapa kesulitan operasional yang melekat pada model CVP dasar:

(1) Struktur Biaya: Sejak memisahkan biaya semi variabel ke elemen tetap dan variabel adalah jantung analisis CVP, semua pengambil keputusan harus menyadari sepenuhnya dan memahami, struktur biaya operasi mereka, maka CVP analisis akan memberikan informasi berarti.

(2) Perilaku Biaya: Model dasar yang menganggap biaya tetap dan biaya variabel per unit tetap konstan. Namun demikian, biaya tidak selalu berperilaku dalam cara yang biasanya diasumsikan. Biaya tetap tidak boleh secara otomatis digambar sebagai garis horizontal, seperti pada kenyataannya mereka mungkin lebih "berbentuk step", dengan masing-masing tahap langkah mewakili berbagai kegiatan di mana biaya tetap tetap konstan. Rentang ini juga dikenal sebagai rentang yang relevan. Selain itu, harus diingat bahwa biaya variabel mungkin lebih lengkung, daripada linier.

(3) Penjualan campuran: Hotel seperti kebanyakan bisnis lainnya bersifat musiman, dan ratio keuntungan/volume (P/V) akan berfluktuasi dari satu komposisi penjualan ke yang lain. Oleh karena itu lebih beragamnya campuran penjualan, semakin besar masalah bagi manajer.

(4) Multi-produk: Mungkin salah satu masalah yang paling penting ketika mempertimbangkan kesulitan operasional model analisis CVP dasar, adalah kenyataan bahwa ada asumsi hanya satu jenis produk/jasa yang dijual. Dalam kasus hotel Welsh, yang memiliki lebih dari satu departemen yang menghasilkan pendapatan, pengguna mungkin perlu kritis untuk menilai kontribusi masing-masing unit/departemen yang ada di hotel. Dalam hal ini pengguna dapat melakukan analisis impas memanfaatkan grafik $\mathrm{P} / \mathrm{V}$.

Pada kasus hotel Welsh, diasumsikan jenis room yang dimiliki ada dua yaitu double dan twin, yang diberi tarif yang sama. Seandainya Welsh memiliki ber-macam2 jenis room dengan tarif yang ber-beda2, maka diperlukan langkah berikut untuk menentukan jenis kamar dan jumlahnya yang harus terjual pada posisi BEP.

Contoh, Ada hotel $\mathrm{X}$ yang memiliki tiga tipe room yaitu suites, double dan single. Masing-masing dengan tarif £140, 2105 dan $£ 70$. Kalau dibobot-kan maka tarif tersebut akan menjadi 2;1,5; 1 (dengan membagi masing-masing dengan £70). Diasumsikan fixed cost ( mis, depresiasi gedung, pemanas, AC) dan variable cost ( mis, linen dan cleaning) totalnya adalah $£ 2,000,000$ untuk room department. Total cost sama dengan total revenue atau titik break even saat total revenue sebesar $£ 2,000,000$. 
Tabel 3. Pendapatan potensial Room Department untuk Hotel X

\begin{tabular}{lllll}
\hline Tipe & Jumlah & Tarif $(\mathfrak{E})$ & $\begin{array}{l}\text { Pendapatan } \\
\text { potensial } \\
\text { harian }(\mathfrak{f})\end{array}$ & $\begin{array}{l}\text { Pendapatan } \\
\text { potensial } \\
\text { Tahunan }(\mathfrak{f})\end{array}$ \\
\hline Suite & 5 & 140 & 700 & 255,500 \\
Double & 80 & 105 & 8,400 & $3,066.000$ \\
Single & 40 & 70 & 2,800 & $1,022,000$ \\
& 125 & & 11,900 & $4,343,500$ \\
\hline
\end{tabular}

Sumber: Data diolah

Dengan kata lain tingkat akupansi saat BEP adalah $£ 2,0000,000 / £ 4,343,500=$ $46 \%$, lihat ke tabel 3, pendapatan harian untuk mencapai BEP adalah $46 \%$ dari $£ 11,900=£ 5,474$ atau sekitar 79 kamar. HOD bisa mengetahui, dengan asumsi kamar terjual sesuai dengan rate yang ditetapkan maka perharinya harus mampu menjual 79 kamar dengan tipe single (79/1) atau 53 kamar dengan tipe double $(79 / 1,5)$ atau dengan kombinasi 1 kamar suite $(1 * 2), 25$ kamar double $\left(25^{*} 1,5\right)$ dan 40 kamar single (40)

\section{SIMPULAN}

Artikel ini menitik beratkan pada penilaian kemungkinan untuk mencapai tingkat keuntungan tertentu pada suatu perusahaan. Namun, metode tersebut bisa diterapkan dengan asumsi distribusi normal, untuk berbagai masalah bisnis dan operasional dalam organisasi. Diharapkan, pendekatan pada artikel ini bisa diterapkan pada area yang berbeda diluar jasa rumah sakit, dimana kata 'uncertainty' dapat diinterpretasikan dan dan dapat dikuantitatifkan. 


\section{DAFTAR PUSTAKA}

Atkinson, et al., Management Accounting Fifth edition, Pearson Internationale Edition.

Dickinson,J.P.,"Cost-Volume-Profit Analysis under Uncertainty”,Journal of Accounting Research. Vol.12 No.1,Spring 1974,pp. 182-7

Don R Hansen, Maryanne M.Mowen, Management Accounting, Seventh Edition, South Western Publishing Co.Cincinnati, Ohio.

Hongren, et al., 2000, Cost Accounting, A Managerial Emphasis, Tenth Edition, Prentice Hall,Inc

Jaediskee,R.K. and Robichek,A.A.,"'cost-Volume-Profit Analysis under Condition of Uncertainty' The Accounting Review, October 1964, pp.917-26

Johnson,G.L. and Simik.S.S.," Multiproduct C-V-P Analysis under Uncertainty", Journal of Accounting Research. Vol 9 No 2, Autumn 1971,pp 278-86

Phillips, Paul A.1994., Cost-Volume-Profit Analysis and Uncertainty, International Journal of Contemporary Hospitality Management, Vol. 6 No. 3, 1994, pp. 3136 (C) MCB University Press Limited, 0959-6119.

Rodriques Maria Eugene, CVP analysis using The Monte Carlo method, Academy of Business \& Administratif Sciences, 1990, Internationale Conference

Usry, F Milton and Carter.William K, Cost Accounting, 13 th Edition, Thomson Learning Custom Publishing,Cincinnati Ohio,2002 